Page 146-156. ISBN: 978-602-6 988-75-1

Web Jurnal Online: jurnal.unmuhjember.ac.id

By: Bramantyo Tri Asmoro; Mimin Anwartinna; Sri Handayani

Tourism Awareness Groups (Pokdarwis) Institutional Capacity Development In

Managing CobanPandawa Tourist Attraction

\title{
TOURISM AWARENESS GROUPS (POKDARWIS) INSTITUTIONAL CAPACITY DEVELOPMENT IN MANAGING COBAN PANDAWA TOURIST ATTRACTION
}

\author{
Bramantyo Tri Asmoro, Mimin Anwartinna, Sri Handayani \\ IlmuPemerintahan FEIS UNIRA Malang, Jl Mojosari 2 Kepanjen, Malang, Indonesia \\ email: bramtriasmoro@gmail.com
}

\begin{abstract}
Based on Law No. 6 of 2014 concerning Villages, villages have more autonomy in carrying out local potential-based development, one of which is the development of tourism villages. Meanwhile, the development of tourism villages cannot be separated from the presence of Tourism Awareness Groups (Pokdarwis), which based on regulation, communities are allowed to participate as perpetrators of tourism village development other than the village government. Pokdarwis is an independent organization, so it is not unsual if Pokdarwis are finally vacuumed in developing tourism destinations, one example of which is PokdarwisSukodono Village, Dampit District, Malang Regency, which vacuumed after it has been running in an effort to manage CobanPandawa tourist attractions in Sukodono Village. This phenomenon is interesting to study because Pokdarwis should be able to be present as a medium to increase tourism-based village development, but on its journey it is vacuum operating. Structural theory Anthony Giddens is considered appropriate as an effort to analyze the above phenomenon, where Pokdarwis is seen as an agency in tourism village management practices, the structure is interpreted as a rule that intersects Pokdarwis which will then be seen in the dialectic process between the two elements. The research aimed to identify the problems that caused the Pokdarwis vacuum and how to increase the role of Pokdarwis in managing CobanPandawa tourist attractions by revitalizing the organization. The study was conducted with a qualitative descriptive method. Data search is done through interviews and field observations. The results of the study are the lack of understanding of the community in carrying out the duties, principles and functions of the Pokdarwis organization and the need to increase institutional and HR capacity in running the Pokdarwis organization.
\end{abstract}

Keywords :Tourism Awareness Group, Structural Theory, Institutional Capacity 


\section{INTRODUCTION}

Indonesian Government created Law No. 6 of 2014 concerning Village, which aimed to strengthen the village as a legal community unit recognized in the system of government of the Unitary State of the Republic of Indonesia. As a result, villages, through the representation of village government, have more autonomy in developing its regions in accordance with their local potency. The government considers that the village not only be developed but must be empowered, so that villages can becomes an independent and strong organization in carrying out development in accordance with the needs of their respective village areas. One of the strategies undertaken by the village government in building its territory is to develop tourism by carrying out the theme of tourism villages.

Tourism is an activity of visiting certain places for recreational purposes, personal development or studying local uniqueness offered by tourist attractions. Tourism development is an integral part of national development for the welfare of rural communities. The development of village tourism in modern era cannot just be dominated by the government, especially the Indonesian territory are very broad and has diverse local potency and wisdom. Collaboration and synergy between related parties, namely the government, the community and the private sector are needed in conducting tourism development activities as shown in Figure 1.

1

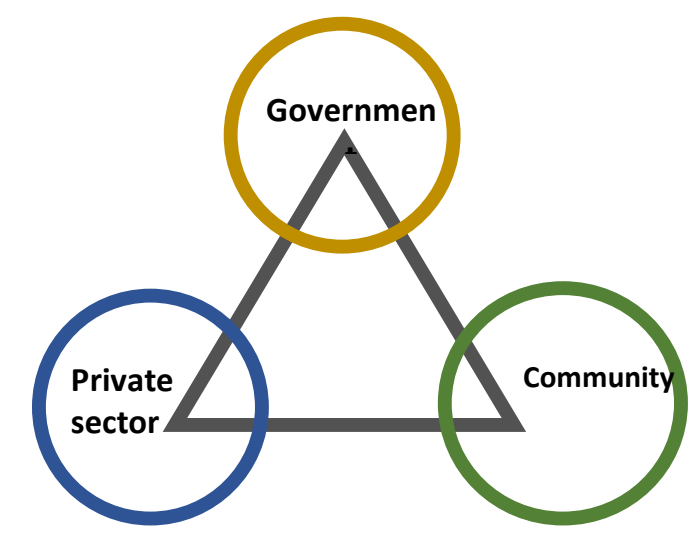

Figure 1. Tourism Development Actors

Based on Figure 1, there are three actors who must work together in tourism development in the region. The first party is government that functions as a regulator, or the party that makes regulation as the basis of the legal umbrella in the development of tourism. The second party, namely the private sector, is a business actor or tourism industry that has networks, capital and resources in supporting tourism development activities. The third party is the community, which has an important position and role in the success of tourism development in the region. Based on Ministry of Home Affairs Regulation (Permendagri) Number 33 of 2009 in Article 9, states that ecotourism development actors are individuals and / or legal entities, in addition to the regional government. Based on these regulations, the community is given more space to become a tourism development actor, because the community is not only play a role as a tourist, but 
also as a host of tourist attraction for visiting tourists. The community is considered to have resources, namely customs, traditions and culture that are able to support tourism development in the region.

Individuals or community who have concern and play an active role in managing tourism objects in their area are called Tourism Awareness Groups (Pokdarwis). Pokdarwis is a form of institution that exists in society, consisting of tourism actors who have care and responsibility, and play a role as a driving force in supporting the creation of a conducive atmosphere for tourism development (Pokdarwis Manual, 2012). The common purpose of forming Pokdarwis is to manage tourism objects in the area, but there are other purposes behind it. It is hoped that Pokdarwis will be able to become a motivator, mobilizer, communicator and even coordinator in increasing awareness, concern and readiness of the community around tourism objects to become good hosts for visiting tourist. The end goal is to increase the community awareness of the opportunities and value of the benefits gained in developing tourism objects to improve the economic well-being of the community. Pokdarwis is a self-help and independent organization group so the membership of Pokdarwis is voluntary, it requires a very strong commitment to run the organization.

Pokdarwis must follow general policies made by the Ministry of Culture and Tourism, which is SaptaPesona, in devoping tourism in the region. SaptaPesona is seven charms that must be fulfilled in order to create a conducive and ideal tourist environment, in hopes of increasing tourist visits. SaptaPesona charms elements are Safe, Order, Clean, Cool, Beautiful, Hospitable, Remembrance. The Government of Malang Regency translates the concept of SaptaPesona with the slogan "The Heart of East Java", in developing tourism attraction in Malang Regency. The Heart of East Java jargon promoted by the Malang Regency Government spurred a variety of mainstay tourism destinations. Made Arya Wedhantara, Head of Tourism and Culture Agency Malang Regency, said that Pokdarwis was a priority program of the Malang Regency Government under the leadership of Regent RendraKresna. "The hope is that Pokdarwis will be established in 379 villages. This is the work priority and instruction of Regent RendraKresna in developing community-based tourism in Malang Regency" (news.detik.com, 2018). The development of the tourism villages through Pokdarwis as a driving force at Malang Regency continues to increase. Based on the records of the Tourism and Culture Agency Malang Regency, the number of Pokdarwis has increased, from only five pokdarwis in 2013, up to eighty-five pokdarwis in 2018.

The increasing numbers of pokdarwis organization raise a question, whether all Pokdarwis who have been established can contribute significantly in the development of tourism in the region. Moreover Malang Regency has a very wide area, making it difficult for Malang Regency Government, in this case Tourism and Culture Agency (Disbudpar), in conducting Pokdarwis supervision, socialization and guidance. The fundamental problem in forming and running the Pokdarwis organization is the awareness and great will of the community in developing the potency that exists in their region. This problem occurred in PokdarwisSukodono Village, Dampit District, Malang Regency. PokdarwisSukodono Village was formed from the initiative of the community, especially 
the people of Wonorejo Hamlet, to manage the CobanPandawa tourist attraction in Sukodono Village. The Pokdarwis was formed by the community in 2018 and was able to carry out activities in the development of CobanPandawa, but Pokdarwis then vacuumed since January 2019. This research identified problems that caused pokdarwis vacuum and factors that can increasing institutional capacity to enhance the role of Pokdarwis in developing CobanPandawa.

\section{METHODS}

This research uses descriptive qualitative research with case studies as supporting analysis. This study focuses on looking at the dynamics of the activities of Pokdarwis in Sukodono Village in terms of CobanPandawa tourism management. The research location was in Wonorejo Hamlet, Sukodono Village, Dampit District, Malang Regency. Research techniques use interview methods, literature studies and observations. The informants chosen were members of the PokdarwisSukodono Village and Sukodono Village Officials.

\section{FRAMEWORKS}

\subsection{Structural Theory}

Anthony Giddens Structural Theory is considered appropriate for analyzing this research because this study seeks to examine how Pokdarwis activities are related to CobanPandawa tourism management. Basically, the structural theory of Anthony Giddens is to reconcile the two points of view namely, structuralist and behavioralist. The structuralist view sees that the structure determines the behavior of the actor. While behavioralist see the behavior of actors in explaining social reality without a decisive structure. Giddens tries to see the structure and behavior of the actor (agency) as duality, something that is complementary rather than conflicting dualism. In essence, structuration theory lies in three main concepts, about "structure", "system", and "structure duality", more specifically in the relationship between agents (actors) and structures (Nashir, 2012: 1).Giddens is aware that the structure is dominant. According to Giddens, "structure refers not only to the rules implied in the production and reproduction of social systems but also on resources" (Giddens, 2001: 30). Structures have important aspects (rules and resources) that are recursively involved in institutions, which are always produced and reproduced, have a duality relationship with the agency and give birth to various social practices as well as social actions (Nashir, 2012: 2). Giddens continued, "the structural concept offered to find the relationship of transformation and mediation as the 'button circuit', which underlies the concepts of observed system reproduction" (Giddens, 2001: 31). In addition, the structure is not only understood as limited to the state, but the structure can also be understood as values that are as rigid. Structures in the Giddens concept are rules and resources. Structures are not constraints, but are constraining and on the other hand enabling agents. Giddens divides the structure into three structural groups, significance, dominance, and legitimacy. Significant structure refers to meaning or symbolic, naming, and discourse. The domination structure refers to ownership of both 
people and goods. The legitimacy structure refers to normative rules that appear in the rule of law (Haryanto, 2009: 136).

Giddens in Haryanto (2009), calls the actor or agency to have three dimensions of agency internal awareness. First, unconscious motivation (unconcious motives) is the desire or need that has the potential to direct action. Second, practical consciousness refers to a group of praxis knowledge that cannot always be decomposed. Finally, discursive consciousness manifests itself in the capacity to reflect and give explicit explanations or actions. Giddens associates structure and social action in agency relations, which gives birth to social practices in people's lives that occur in a structured or structured pattern and not as a coincidence (Nashir, 2012: 6).

\section{RESULT}

\subsection{Management Practices of CobanPandawa Tourist Atrraction}

CobanPandawa is located in Wonorejo Hamlet, Sukodono Village, Dampit District, Malang Regency, about $50 \mathrm{~km}$ from Malang City, $18 \mathrm{~km}$ from the center of Dampit District. CobanPandawa, as the name suggests has five waterfalls in one location. The five waterfalls have different views. Starting from the lowest to the highest waterfall. The five waterfalls have an average height of 15 meters and have a fairly heavy flow, but are safe and comfortable to enjoy. The management pattern of tourism management activities still upholds mutual cooperation and friendliness. Community habits are used as the basis for the management of CobanPandawa tourist attraction.

At first, the natural potency at Sukodono Village were not yet considered as potential that could be explored and had a positive impact. Over time, the needs of recreational facilities for the community was increasing and discussions began to explore the potential of CobanPandawa. The understanding of the community about the potential of nature that can be utilized and have an impact on increasing community welfare began to arise. Thoughts about obstacles, challenges and solutions arises during deliberations in the community. This process was initially initiated by several individuals who made a social approach to the community about the potential possessed by Sukodono Village. The community together with the village officials then held a meeting to study tourism potential in Sukodono Village. Deliberations conducted resulted in the decision to name the waterfall as CobanPandawa and the management of CobanPandawa as a tourist attraction.

During the meeting, there was also an agreement to establish the structure of the Tourism Awareness Group (Pokdarwis) of Sukodono Village, with the aim of maximizing the management of CobanPandawa. The work program that was first carried out by Pokdarwis was voluntary work and mutual assistance every week by all residents around tourist sites. The program which initially only ran once a week, increased up to twice a week, but in its journey the program of voluntary work and mutual cooperation stopped. Not only the program that stopped, but since January 2019, the Pokdarwis organization is also vacuuming in developing CobanPandawa activities. 
Page 146-156. ISBN: 978-602-6 988-75-1

Web Jurnal Online: jurnal.unmuhjember.ac.id

By: Bramantyo Tri Asmoro; Mimin Anwartinna; Sri Handayani Tourism Awareness Groups (Pokdarwis) Institutional Capacity Development In Managing CobanPandawa Tourist Attraction

Based on interviews conducted with several Pokdarwis members, the vacuum of the Pokdarwis organization was caused by several factors, namely the lack of understanding of the roles and tasks, main and functions of the organization, constraints on organizational legality, limited supporting facilities and main activities of Pokdarwis members. These factors illustrate the lack of communication and interaction among internal members of Pokdarwis and between Pokdarwis and Village Government are the cause of the organization's vacuum.

\subsection{Management Constraints of CobanPandawa Tourist Atrraction}

The results of observations and interviews show that in general, the constraints of organization's vacuum can be identified from human resources and organizational aspects. Both are inseparable because they are interrelated, so increasing organizational capacity also requires increasing the capacity of organizational members. Giddens' structuration theory places power in the actor (Nashir, 2012: 6), so even though there is a restraining structure, the actor has the capacity to influence the structure (through power).

\section{- Human Resources Capacity}

Professional management of tourist attraction requires a strong commitment and managerial ability, so it is expected that increased tourist visits at tourist attraction have a positive impact on the welfare of the community. In terms of quantity, there are quite a lot of people (50 members) who are members of Pokdarwis. Cultural potency such as hospitality and mutual cooperation in the community also supports the development of CobanPandawa as a tourist attraction. But from the large number of Pokdarwis members, if viewed in terms of quality, only a few members have an awareness and commitment in running the organization. Pokdarwis is a community group organization that is independent, in which there is a organizational structure that has duties, principles and functions in support of SaptaPesona.

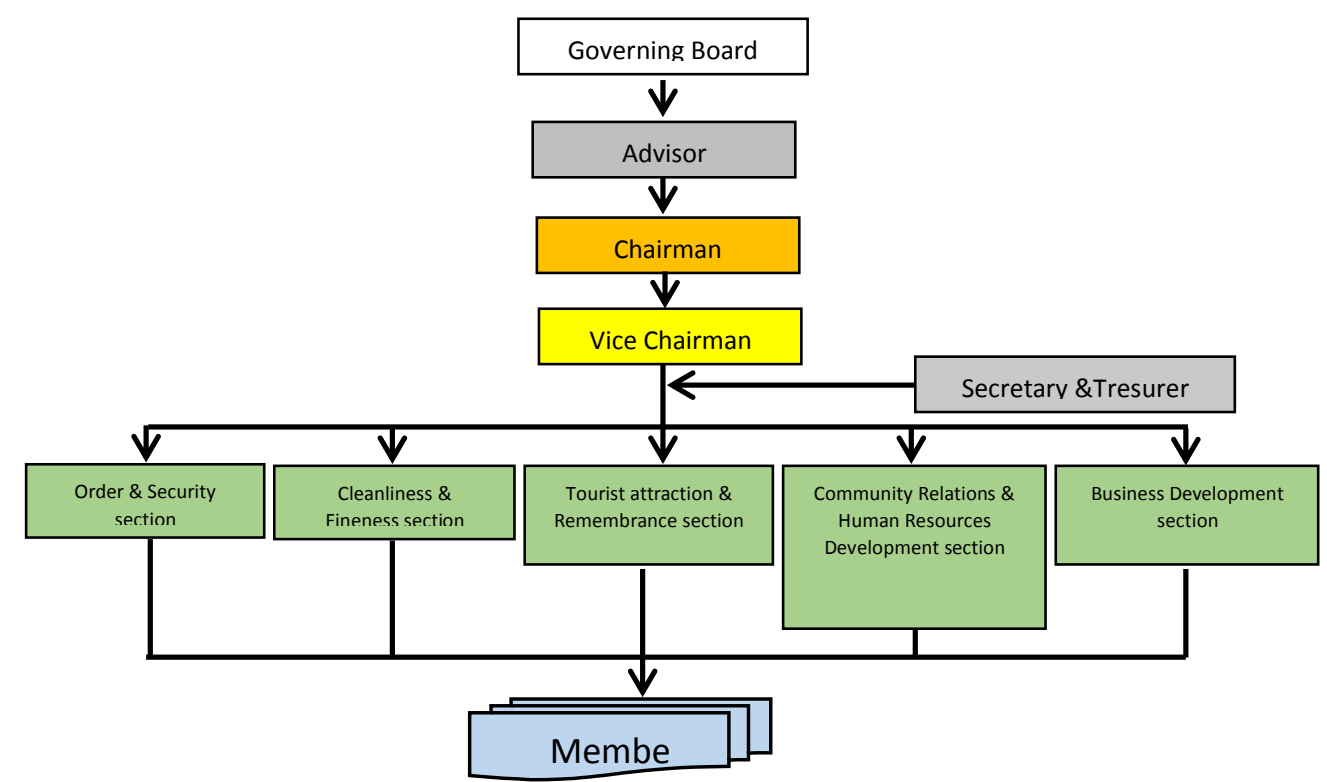

Figure 2. Pokdariws Organizational Structure 
The organizational structure in PokdarwisSukodono Village are similar to Figure 2, but not all members of Pokdarwis work in accordance with the structure that has been formed, due to lack of understanding of the importance of the organization (Pokdarwis) in managing tourism objects and lack of skills in terms of organizational management. In addition to being a driving force, Pokdarwis is expected to play a role as a motivator and communicator in providing understanding to the community to be a good host for tourists. The limited financial operations in developing CobanPandawa are also a challenge, in the end, Pokdarwis only passively waits for funding from the village government in developing tourism objects.

\section{- Organizational capacity}

Pokdarwis is an independent community group organization, but to legalize Pokdarwis, a Decree (SuratKeputusan) is issued by the village government. The decree from the village then used as the basis for the Tourism and Culture Agency in the area to issue an official decree on Pokdarwis legality. The legality of PokdarwisSukodono Village had become a prolonged tug-of-war so that it became one of the causes of Pokdarwis's vacuum. This is because the village government had issued a Pokdarwis decree which was a polemic with Pokdarwis because it was different from the agreement that had been produced in the meeting.

The lack of organizational management skills of Pokdarwis members also ultimately adversely affected organizational performance, organizational income was not optimal because there were no regulations on regulating entry ticket prices, operational hours of ticket counters is not optimal and unclear revenue sharing for parking spaces using residents' houses. Even the organizational income that are obtained is not recorded through financial statements that should be made periodically. Tourist visits which reach 100-200 tourist each week do not contribute maximum income to Pokdarwis. The lack of organizational income caused the improvements, additions to infrastructure and supporting facilities as carrying capacity to attract tourists is not optimal due to limited operational funding.

The diminishing interaction between Pokdarwis and the village government also caused miscommunication in the technical management of CobanPandawa. The village government hopes that Pokdarwis can become an independent and professional organization before entering into a business unit within the BUMDes so that they can get financial support, while Pokdarwis hopes to get assistance and finance from the village government in developing CobanPandawa tourism objects.

\subsection{Structure Theory in the Management of CobanPandawa Tourism Attraction}

The Giddens structure theory is used to analyze this research because Giddens views that the meeting point between agents and structures produces a social practice. In simple terms, the interaction between structure, agent and agency can be interpreted as a dialectical process to reach consensus. The management of CobanPandawa tourism objects is carried out by people around tourism objects which are then incorporated into Pokdarwis (agents), where Pokdarwis then runs based on existing rules (structure) but the problem is that the legality of the rules binding Pokdarwis remains unclear. Agents are actors who are in contact with structures (passive), but agencies are actors who interact 
Page 146-156. ISBN: 978-602-6 988-75-1

Web Jurnal Online: jurnal.unmuhjember.ac.id

By: Bramantyo Tri Asmoro; Mimin Anwartinna; Sri Handayani Tourism Awareness Groups (Pokdarwis) Institutional Capacity Development In Managing CobanPandawa Tourist Attraction

actively with structures. Structures are standard values that are interpreted not only as regulations or rules, but tradition or culture can also be categorized as structures because they store values that same as hard. Then it can be said that dialectics is the process of interaction (active) between structure and agency.

The structural logic in Giddens's view is described as below:

structure

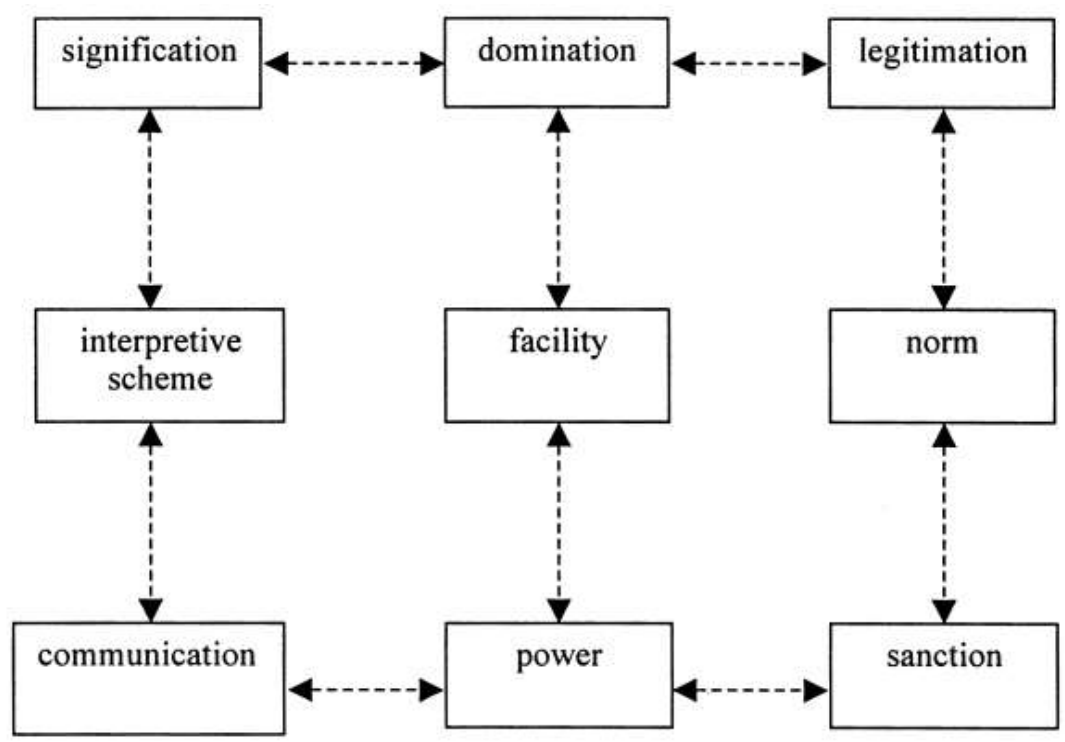

Figure 3. Structure Giddens Logic

Scheme Figure 3 explains that something can be called a structure if it has an element of significance, dominance and legitimacy. This means that the structure has the power to be able to provide a framework for action. A means is to function as a liaison before the structure can become an interaction or patterns of action. The liaison referred to is in it there are values that are capable of binding action. Therefore, the facilities have elements of interpretation, facilities, and norms, where the three elements are things that are capable of supporting the structure. Furthermore, interaction is the stage where the structure can be run. Therefore, in interactions, the patterns used are related to communication, power, and sanctions. Further explanation, communication is one of the interaction processes for carrying out the structure. Besides that the structure can also be used in the interaction of power, where action always involves power. Sanctions are interactions that are used by structures in the event of structural deviations. 
Page 146-156. ISBN: 978-602-6 988-75-1

Web Jurnal Online: jurnal.unmuhjember.ac.id

By: Bramantyo Tri Asmoro; Mimin Anwartinna; Sri Handayani Tourism Awareness Groups (Pokdarwis) Institutional Capacity Development In Managing CobanPandawa Tourist Attraction

\begin{tabular}{|c|c|c|}
\hline \multicolumn{3}{|c|}{ Structure Theory } \\
\hline Signification & Domination & Legitimation \\
\hline $\begin{array}{l}\text { 1. Community awareness } \\
\text { and commitment in } \\
\text { managing } \\
\text { CobanPandawa } \\
\text { through pokdarwis. } \\
\text { 2. Matching the vision } \\
\text { between the village } \\
\text { government and } \\
\text { Pokdarwis in the } \\
\text { management of } \\
\text { CobanPandawa. } \\
\text { 3. Independent and } \\
\text { Professional Pokdarwis }\end{array}$ & $\begin{array}{l}\text { 1. Village Government } \\
\text { acts as a facilitator. } \\
\text { 2. Fix pricing of ticket } \\
\text { counters and parking. } \\
\text { 3. Distribution of income } \\
\text { benefits between } \\
\text { citizens and } \\
\text { organizations. }\end{array}$ & $\begin{array}{l}\text { 1. Pokdarwis charter. } \\
\text { 2. Pokdarwis legality. } \\
\text { 3. Village regulations } \\
\text { about Pokdarwis. } \\
\text { 4. Village regulations } \\
\text { about village-owned } \\
\text { business entity } \\
\text { (BUMDes). }\end{array}$ \\
\hline
\end{tabular}

Figure 4. Structure in CobanPandawa Management

Based on Figure 4, Significance describes the meaning of the basic essence of Pokdarwis as an organization that function to develop CobanPandawa. The community already has an awareness that if CobanPandawa is well managed, it can improve people's welfare. However, the awareness and commitment that was built together between the community and the village government with the creation of Pokdarwis, slowly encountered several obstacles, including limited management skills of Pokdarwis member organizations, lack of interaction between Pokdarwis members and the relation between pokdarwis and village governments, resulting in different perspectives in achieving a shared vision. The village government hopes that Pokdarwis can be independent without funds from the village government, but to become an independent Pokdarwis, the village government still has an obligation to provide regular assistance in empowering its citizens.

Domination describes ownership, the village government is the authorized authority in Sukodono Village, so it has an obligation as a facilitator in empowering its citizens. Periodic assistance in increasing pokdarwismembers capacity and organizational capacity needs to be carried out continuously by village government. It is hoped that Pokdarwis can become an independent organization, especially from the financial side, so that Pokdarwis can carry out the task of being a motor and communicator in tourism management. Continuous assistance by the village government can also reduce the potential conflict when Pokdarwis becomes a tourism unit within BUMDes.

Legitimacy describes norms or rules, because a strong legal basis is needed in a structure. The pokdarwis charter is needed as a guideline in running an organization, because it regulates rules and sanctions that binding pokdarwis members. The legality of Pokdarwis which is a polemic also needs to be discussed to find a joint solution, because with the legality from the Malang Regency Tourism and Culture Agency (Dinparbud), pokdarwis can access the grant program from the relevant agencies and get information 
updates from the Regency Tourism and Culture Agency. Village regulations regarding Pokdarwis are also needed to regulate pokdarwis authority and technical matters such as ticket prices and parking lot in CobanPandawa. Communication and interaction with Pokdarwis also needs to be carried out periodically by the village government, regarding plans for managing village potential under BUMDes, including the possibility of pokdarwis which will become a tourism unit within the BUMDes. The agreement that was established also needs to be poured into village regulations so that there is no conflict in managing CobanPandawa.

\section{CONCLUSION}

Pokdarwis can be seen as two actors namely agents and agencies, because in its membership participation, only a portion of members have an awareness of organization (agency) and some still lack understanding of Pokuparwis duties. The not yet optimal agency working in Pokdarwis has finally affected the sustainability of the Pokdarwis organization and has implications for the stagnant management of the potential of the CobanPandawa village. The structure is defined by regulatory uncertainty that binds Pokdarwis. This ambiguity has implications for the loosening of Pokdarwis operations both in terms of human and organizational resources. In this case the village government should be able to become a mediator in the formation and assistance of regulations on Pokdarwis so that the overall operation of Pokdarwis can run optimally.

The dialectical process that occurred at the beginning of the pokdarwis creation was an understanding in the management of village potency (duality), it was clearly seen when pokdarwis and the village government jointly started cleaning the tourist sites of CobanPandawa. But there had been dualism amid the fluctuations in management of Pokdarwis and village potency (CobanPandawa). This was apparent when Pokdarwis hoped for assistance and financial assistance from the village government, while the village had the logic that Pokdarwis had to stand independently before it could be included as a business unit in BUMDes, which could then be budgeted for management funding. The decrease in the intensity of interaction and communication between Pokdarwis and the village government could be one of the reasons for the pokdarwis vacuum.

Village government must increase its role as regulator and facilitator to pokdarwis through regular assistance. The role of the regulator that must be carried out by the village government among others are to legalize the Pokdarwis organization through village decree with a mutual agreement, to obtain legality from the Malang Regency Tourism and Culture Agency. Village regulations must also be made to regulate the existence of Pokdarwis and the transformation of Pokdarwis into a business unit within BUMDes. The role of the facilitator that the village government must do among others are to provide assistance and training to members of Pokdarwis regarding organizational management so that it is hoped that Pokdarwis can become an independent and professional organization in the management of CobanPandawa. 
Page 146-156. ISBN: 978-602-6 988-75-1

Web Jurnal Online: jurnal.unmuhjember.ac.id

By: Bramantyo Tri Asmoro; Mimin Anwartinna; Sri Handayani Tourism Awareness Groups (Pokdarwis) Institutional Capacity Development In Managing CobanPandawa Tourist Attraction

\section{REFERENCES}

Giddens, Anthony. 2001. Constitutions of Society :Teori Strukturasiuntuk Analisa Sosial, Yogyakarta, Pedati.

Buku Pedoman Kelompok Sadar Wisata. Kementerian Pariwisata. (2012). http://www.kemenpar.go.id/userfiles/1_\% 20Pedoman\%20Pokdarwis.pdf

Peraturan Menteri Dalam Negeri Nomor 33 Tahun 2009 Tentang Pedoman Pengembangan Ekowisata di Daerah

Undang-UndangNomor 6 Tahun 2014 TentangDesa

Undang-UndangNomor 10 Tahun 2009 TentangKepariwisataan

Haryanto, 2009. Elit Politik Lokal dalam Perubahan SistemPolitik, JurnalSosialPolitik UGM Volume I Nomor 2, November 2009.

Nashir, Haedar, 2012. Memahami Strukturasi Dalam Perspektif Sosiologi Giddens, Jurnal Sosiologi Reflektif Volume 7 Nomor 1 Oktober 2012.

Nugroho, Sapto. 2016. Praktik Geowisata Karang sambung Kebumen :Tinjauan Perspektif Dualitas. JUMPA Volume 3 Nomor 1 Juli 2016.

Syah, Firman. 2017. StrategiMengembangkanDesaWisata. Prosiding Seminar Nasional Multi DisiplinIlmu\&Call For Papers Unisbank K3-3 (Sendi_U3) 2017. ISBN: 9789-7936-499-93.

Yudasuara, I Ketut. 2015. PengelolaanDaya Tarik WisataBerbasisMasyarakat di DesaPecatu, Kuta Selatan, KabupatenBadung. JUMPA Volume 2 Nomor 1, Juli 2015. 